\title{
Impact of the COVID-19 pandemic on the dental service: A narrative review
}

\author{
Michalina Lewandowska ${ }^{1, B, D}$, Mirella Partyka ${ }^{1, B, D}$, Paulina Romanowska ${ }^{1, B, D}$, Klara Saczuk, ${ }^{2, D, E}$, Monika Magdalena Lukomska-Szymanska ${ }^{2, E, F}$ \\ ${ }^{1} 4^{\text {th }}$ grade student, Faculty of Dentistry, Medical University of Lodz, Poland \\ ${ }^{2}$ Department of General Dentistry, Medical University of Lodz, Poland \\ A - research concept and design; $\mathrm{B}$ - collection and/or assembly of data; $\mathrm{C}$ - data analysis and interpretation; \\ $D$ - writing the article; $E$ - critical revision of the article; $F$ - final approval of the article
}

Address for correspondence

Monika Magdalena Lukomska-Szymanska

E-mail:monika.lukomska-szymanska@umed.lodz.pl

Funding sources

None declared

Conflict of interest

None declared

Received on January 12, 2021

Reviewed on May 7, 2021

Accepted on May 19, 2021

Published online on December 31, 2021

Cite as

Lewandowska M, Partyka M, Romanowska P, Saczuk K,

Lukomska-Szymanska MM. Impact of the COVID-19 pandemic

on the dental service: A narrative review. Dent Med Probl.

2021;58(4):539-544. doi:10.17219/dmp/137758

DOI

$10.17219 / \mathrm{dmp} / 137758$

Copyright

○) 2021 by Wroclaw Medical University

This is an article distributed under the terms of the

Creative Commons Attribution 3.0 Unported License (CC BY 3.0)

(https://creativecommons.org/licenses/by/3.0/).

\begin{abstract}
This article describes what changes have had to be made to the functioning of dental practices due to the COVID-19 pandemic and how the pandemic has affected dental staff. Dentists are at high risk of infection and this is associated with fear, including the fear of being infected by their co-workers and patients, or that they will infect their families. The introduced changes include increased protective measures, and the introduction of additional questionnaires and procedures. In dental practices, the use of personal protective equipment (PPE) has been increased and changes have been introduced in the functioning of surgeries in accordance with the recommendations of dental associations and governments. The aforementioned changes have significantly reduced the comfort of dental work, increased the costs of treatment and reduced the availability of dental treatment. A novel solution to this situation has been the implementation of teledentistry, which helps to reduce the number of non-emergency visits. This process involves the remote facilitation of dental treatment by means of technology (i.e., phone or the Internet) without direct contact with the patient. Due to the restrictions implemented during the pandemic, many universities have introduced remote or hybrid teaching for both didactic and practical classes.
\end{abstract}

Keywords: dentistry, dental practice, dental education, COVID-19, pandemic 


\section{Introduction}

Severe acute respiratory syndrome coronavirus 2 (SARS-CoV-2) is the $7^{\text {th }}$ virus in the coronavirus family. This virus is very easily transmitted by contact with infected individuals, both symptomatic and asymptomatic. ${ }^{1}$ Restricting out-of-home movement, social distancing, the cessation of almost all work activities, and wearing protective masks and gloves are intended to minimize the transmission coronavirus disease 2019 (COVID-19). ${ }^{2}$ The COVID-19 pandemic has had a significant impact on the lives of all human beings. ${ }^{3,4}$ Contact with other people has been reduced or eliminated, which has significantly affected mental health along with personal and professional life. ${ }^{5,6}$ Medical professions, depending on their specialization (different distances between workers and patients), are exposed to infectious agents to varying degree. ${ }^{7}$ Dentists are most at risk of COVID-19 infection, even more than nurses and general practitioners. ${ }^{2}$ This fact results from immediate contact with the oral cavity, where the virus is present. Moreover, water spray, which can reach up to 2-3 $\mathrm{m}$ from the patient's mouth, considerably increases dental personnel's exposure to the virus. ${ }^{8,9}$ This has resulted in many changes in the functioning of dental practices. $^{10,11}$

The aim of this article was to describe and discuss changes in the availability and quality of dental services and dental education during the COVID-19 pandemic based on a review of the literature.

\section{Method}

The selected articles were obtained by searches, using Google Scholar and PubMed. The selection of scientifically valid sources took place between December 1 and 29, 2020. The following keywords were used: 'COVID-19'; 'SARS-CoV2'; 'pandemic'; 'coronavirus'; 'dentistry in the pandemic'; 'teledentistry'; 'dental education'; 'stress'; 'protective measures in the pandemic'; 'psychological impact'; and 'mental health.' Out of 96 retrieved articles, 51 items were selected for this paper. Bibliographic reviews, systematic reviews, meta-analyses, cohort studies, and studies in English, Polish or Croatian were included. The exclusion criteria were as follows: articles not related to the topic; animal studies; full text not available; and articles in other languages. No time limits were applied during the screening phase with regard to the scientific articles.

\section{Psychological consequences of COVID-19}

At the onset of the pandemic, there was no knowledge on the transmission of SARS-CoV-2, and therefore no guidelines were introduced. As a result, dentists did not fully know how to proceed, and the first reaction of many of them was to close down their offices at the end of March 2020. ${ }^{12}$

Doctors' main concerns were the fear of infecting their family, their own safety and the awareness of the mortality due to COVID-19 infection. ${ }^{13,14}$ Healthcare workers were not immune to the psychological consequences of COVID-19. ${ }^{15}$ They were at higher risk of developing anxiety, depression and high levels of stress during the outbreak of SARS-CoV-2. ${ }^{15,16}$ The reasons for this included excessive workload, inadequate personal protective equipment (PPE) and the feeling of being inadequately supported. ${ }^{15,17}$

The concern about being infected with COVID-19 by a patient was a major psychological strain. ${ }^{14,18}$ Furthermore, psychological distress has been identified as a cause of the potential reduction in the quality of treatment provided. It seems that young practitioners became more stressed when the spread of COVID-19 accelerated. It was noted that decision-making skills, clinical experience, the ability to deal with the encountered difficulties, and job satisfaction were higher in specialized dentists, who managed stress more effectively than novices. ${ }^{19}$ the aim of this study was to evaluate the level of perceived stress (PS Moreover, dentists working within the private sector (clinics and/or institutions) experienced higher levels of stress than dentists working in hospitals or state institutions. ${ }^{19}$

A survey conducted in March 2020 among 650 dentists from 30 countries in Europe, Asia, Australia, and North America showed that $66 \%$ of respondents wanted to close their practices until a significant decrease in COVID-19 cases, $87 \%$ of individuals were afraid of being infected, $92 \%$ had concerns about infecting family members, and $72 \%$ felt nervous talking to a patient in close proximity. ${ }^{10}$ Moreover, a survey conducted in April 2020 among 365 dentists in Northern Italy reported that $6.2 \%$ of respondents experienced anxiety intensely, $37.4 \%$ experienced it lightly and $23.6 \%$ experienced it moderately. ${ }^{20}$ Intense sadness was felt by $12.6 \%$ of individuals and intense anger by $9.3 \%$, while $44.1 \%$ of respondents did not experience anger at all. ${ }^{20}$ In conclusion, health professionals experienced different emotions and moods at different levels, but anxiety and stress were the most common. The fear of infection was inherent in the experiences of dental professionals.

\section{Changes in the organization of dental practices}

In the dental practices which were reopened or were not previously closed, increased personal protection measures and changes in the functioning of these practic- 
es were applied in accordance with the rapidly changing recommendations from dental associations and governments. ${ }^{8,21}$ Dentists were to avoid planned patient treatment during the COVID-19 pandemic, with only pain patients being treated and those needing urgent assistance. ${ }^{2,21}$ The recommendations also included abstaining from the aerosol-generating procedures which involve using a turbine, a handpiece or air-water syringes. Unfortunately, these instruments are necessary to achieve the right quality of treatment. ${ }^{22}$

Changes in the functioning of dental practices included larger intervals between patients and fewer patients being treated to prevent contact in the waiting room, increased frequency of disinfection, taking additional medical history of the potential contact with a coronavirus patient or COVID-19 symptoms, and more restrictive treatment protocols. ${ }^{8,21}$ The SARS-CoV-2 virus can persist on surfaces from a few hours to several days, depending on the type of surface, temperature or humidity. This reinforced the need for thorough disinfection of all surfaces in the dental practice. ${ }^{23}$ Each area in the waiting room was associated with a risk of infection. Therefore, in addition to ensuring adequate periodic air exchange, all surfaces, chairs, magazines, and doors that could come into contact with medical staff and patients were to be treated as "potentially contaminated". ${ }^{2}$ The complete removal of leaflets and magazines from the dental office was also to be considered. ${ }^{24}$ In order to reduce the number of people in the office, people accompanying the patient were asked to wait outside or in a car, the exception being when the patients were unable to arrive to the appointment by themselves due to their health condition. ${ }^{2}$ In the waiting room, the chairs were taped and marked with social distance signs. ${ }^{24}$ The whole air conditioning system required strict and frequent decontamination. ${ }^{2}$

\section{Protective measures}

Personal protective equipment included N95 or preferably N99 masks (FFP2 and FFP3, respectively), disposable aprons and caps, easily washable shoes, and additional protection of the doctor's eyes and face in the form of a face shield, instead of just protective glasses. ${ }^{8}$ Proper hand hygiene has been identified as the most important factor in reducing the transmission of microorganisms to patients. ${ }^{23}$ Dentists were advised to avoid or minimize situations that may cause the formation of aerosol. The use of high-volume saliva ejectors was advised to reduce the production of droplets and aerosol. ${ }^{2}$ Since the number of pathogens contained in the human saliva is very high, rinsing the mouth with antiseptic liquids can reduce the amount of infectious particles, but cannot eliminate the virus from the saliva entirely. ${ }^{2}$ Many products, such as chlorhexidine $(\mathrm{CHX})$, cetylpyridinium chloride (CPC) and essential oils (EO), have been used in oral rinses.
They exhibit antibacterial, antifungal and antiviral properties. ${ }^{25}$ The use of a rubber dam while performing procedures was recommended to reduce contact with the saliva by reducing the number of droplets around the operating field by $70 \%{ }^{8}$ If the use of a rubber dam was not possible, it was recommended to treat the cavities with hand tools. ${ }^{8}$ The use of a face shield was highly recommended. However, the use of magnifying glasses and a microscope was cumbersome due to the bulk of the mandatory attire. ${ }^{8}$ Minimally invasive procedures were also recommended to avoid increased salivary secretion, coughing or vomiting, which also may affect the quality of treatment. ${ }^{8}$ The procedures involving taking tomography or extraoral Xrays instead of intraoral projections were favored. Moreover, the use of scaling or other treatment producing spray needed to be limited. ${ }^{8,12,21}$

In addition, the time required for the treatment of a single patient has been prolonged, due to the initial interviewing of patients for COVID-19-related medical history, pre-qualification surveys for COVID-19 and the measurement of body temperature. ${ }^{26}$

\section{Cost increases}

The aforementioned changes have significantly reduced the comfort of dental work, increased the costs of treatment and reduced the availability of dental services. ${ }^{21}$ Financial stress and anxiety are some of the important aspects of financial mental health, which can impact an individual's cognitive, emotional and relational wellbeing. ${ }^{19}$ According to a telephone survey carried out between March 24 and April 2, 2020 in Germany, carried out after 135 days of restrictions, $12-29 \%$ of practices were not able to cover their operating costs. ${ }^{27}$ The longer the restrictions, and the associated closures, reductions in the number of patients and increases in the amount of new PPE last, the worse off dental practices and clinics will be. ${ }^{27}$

The overall need to introduce the aforementioned additional PPE came with additional costs. Since the start of the pandemic, the costs of personal protective measures and additional disinfectants have increased. ${ }^{21}$ As the number of patients has been reduced and costs have grown, some dentists have been forced to introduce additional fees for each visit or to increase the price of treatment. ${ }^{26}$ A partial economic evaluation was carried out in Brazil, using the activity-based costing method to calculate the purchase of the PPE and decontamination solutions recommended for dental clinical practices during the COVID-19 pandemic. ${ }^{28}$ Two scenarios were compared - pre-COVID-19 and post-COVID-19, by taking prices from at least 3 online quotations made in May 2020. The pre-COVID-19 scenario included the standard use of disposable gloves, disposable masks, disposable caps, disposable coats, and safety glasses. The post-COVID-19 
scenario included the use of disposable gloves, N95/FFP2 masks, disposable masks, disposable caps, disposable shoe covers, waterproof medical coats, disposable gowns, protective goggles, and face shields. Each disposable item was replaced after each patient. The waterproof medical coat was recommended to be used for the whole day. The dentists and dental hygienists were advised to use protective goggles and face shields, which were disinfected between patients. The cost of the protective goggles and face shields was spread over the number of uses and the equipment was recommended to be replaced every 6 months. Prior to the COVID-19 pandemic, the direct costs of biosafety recommendations amounted to $\mathrm{R} \$ 0.84$ per patient, $\mathrm{R} \$ 6.69$ per service shift and $\mathrm{R} \$ 3,413.94$ per year. The post-COVID-19 costs of biosafety recommendations resulted in $\mathrm{R} \$ 16.01$ per patient, $\mathrm{R} \$ 128.07$ per service shift and $R \$ 32,657.96$ per year. The costs of disposable PPE in the post-COVID-19 scenario consisted of R $\$ 122$, which was $95.26 \%$ of the total. ${ }^{28}$ The results of the abovementioned study show that changes in biosafety protocols during the COVID-19 pandemic have significantly increased the costs of dental consultations. ${ }^{28}$ Most fixed costs, such as the staff costs, materials and installments, are difficult to reduce and require redundancies. ${ }^{27} \mathrm{~A}$ large number of costs, such as the costs of disinfectants, PPE and disposable materials, will only grow. ${ }^{20,27}$ Without increases in the service costs, dental clinics will not be able to survive. ${ }^{27}$ However, an increase in the treatment costs means a decrease in the availability of dental services, and, while almost all large- and small-scale sectors are on the verge of losing their ground, the dental healthcare sector is no exception. . $^{19,27}$

\section{Teledentistry}

The closure of dental offices resulted in the lack of proper dental care, and consequently a deterioration in patients' oral health. ${ }^{12}$ However, a new and interesting solution to the situation of the pandemic turned out to be teledentistry. Teledentistry involves the remote facilitation of dental treatment by means of technology (i.e., phone or the Internet) without direct contact with the patient. ${ }^{29}$ It can take the form of a real-time consultation or be realized through the store-and-forward method. ${ }^{30,31}$ A real-time consultation involves a video conference between the doctor and the patient. ${ }^{32}$ Based on the patient's history and clinical symptoms, the dentist makes a decision about the necessity of the patient's appearance at the dentist's office. In situations where dental treatment does not have to be undertaken immediately, appropriate detailed instructions for home medical care should be provided by means of teleinformation and prescriptions should be issued for the recommended medication. ${ }^{1}$ Additionally, the store-and-forward method involves sharing clinical information between specialists for consul- tation and treatment planning. ${ }^{33}$ The patient does not participate in this form of consultation. ${ }^{29,34}$ There may be exchanges between physicians, involving radiographs, graphical representations of periodontal and hard tissues, treatment, laboratory results, photographs, and other information transportable through multiple providers. ${ }^{34}$ A third method has also been described, known as the remote monitoring method, in which patients are monitored remotely in real time, and can be either hospitalbased or home-based..$^{35}$

Teledentistry has the potential to address patients' therapeutic needs and reduce healthcare costs. ${ }^{34}$ It enables redressing the balance in access to dental care for patients in rural areas, nursing homes, and those who have mobility or transportation problems. ${ }^{1,31,36}$ Moreover, it plays an important role in many fields of dentistry and enables rapid diagnoses of patients at a distance. In the case of impacted or semi-impacted third molars, a remote diagnosis brings the same results as a real-time diagnosis. ${ }^{37}$ With the help of teledentistry, orthodontic specialists can prepare, advise, and even supervise general dentists when a patient is unable to see an orthodontist. ${ }^{38} \mathrm{~A}$ diagnosis of caries in young children is performed just as well with teledentistry as it is conventionally. ${ }^{39}$ Of course, it will not replace most dental visits, but at the same time provides many advantages. ${ }^{30}$

\section{Education of future dentists}

Medical and dental universities educating future doctors and dentists are also facing a problem. Many universities have introduced online or hybrid teaching. Social distancing continues to be one of the most effective means of protection against the infection. Therefore, classes with a larger number of students, such as lectures and seminars, have been moved completely to online platforms. ${ }^{40,41}$ All types of knowledge testing, such as exams, colloquia and tests, have been conducted online as well. Whether or not such solutions can produce measurable effects on education will have to be evaluated in the future. $^{40}$

Although e-learning is considered enjoyable by many students, ${ }^{42,43}$ they are still worried about acquiring practical skills entirely through online learning. ${ }^{44}$ Some dental students may have fewer opportunities to practice and develop their manual and practical skills, which are particularly important in dentistry. ${ }^{45}$ Learning on phantoms during pre-clinical classes can only partially compensate for the lack of contact with actual patients. ${ }^{46}$

The fact that students might not learn certain practical skills due to the lack of actual clinical classes could prove to be a major problem. The consequence of this could be an extended transition time from a student to a qualified healthcare professional, due to the need to catch up on their clinical skills. Students of senior years are faced with 
the worst situation, since they will not have time to catch up, in contrast to younger students. Therefore, many universities have prioritized the organization of classes for students who perform clinical procedures. ${ }^{47}$ Many students have therefore expressed the need to return to the traditional form of education in the near future. However, they realize that the way of education may have changed for the years to come. ${ }^{48}$ On the other hand, a positive effect of online education turned out to be that it has encouraged students to expand their knowledge on their own and to use resources provided on the Internet, such as webinars, clinical videos, etc. ${ }^{48,49}$

Changes in the way education is provided have regarded not only students, but also academic teachers, who additionally do clinical work in their own offices. The changes caused by the pandemic have significantly affected both areas of their responsibilities. New solutions and procedures, which continue to be introduced practically overnight, result in increased feelings of stress and anxiety. Doctors who are also academic teachers speak out about the burden they feel particularly during this time of crisis. ${ }^{47,50}$

\section{Overview and future perspectives}

During the course of the pandemic, increased feelings of fear, anxiety and sadness have been observed among dentists. Due to these emotions, many practices closed down at the beginning of the pandemic, making it difficult for patients to access treatment. Changes such as extended breaks between patients and accepting only urgent cases had a similar effect. Increased safety measures, such as additional protective clothing, antiseptics, etc., resulted in increased treatment costs. Increases in prices were not always reimbursed. Choosing alternative methods of treatment may not give equally good results and could result in a lower quality of dental services. However, the full quality of dental treatment during the COVID-19 pandemic will certainly still be examined from a longterm perspective.

Based on the literature, it can be concluded that the longer the pandemic lasts, the higher the stress among medical workers. Personal protective equipment will become part of the daily operation of dental practices. Teledentistry will develop more rapidly and on a larger scale, so that it can be of use to patients more than it used to be. Modern technology and wide access to the Internet could make this possible. The Internet will also play a greater role in the education of future dentists. However, it will not replace practical classes and contact with real patients.

To sum up, the COVID-19 pandemic is forcing changes in the education of dental students as well as in everyday dental practice. It also affects the availability and quality of dental services for patients. Consequently, new procedures have been developed and quickly implemented into everyday work. Until the epidemiological situation calms down, the changes introduced will stay with us longer and could possibly last forever.

\section{ORCID iDs}

Michalina Lewandowska (D) https://orcid.org/0000-0001-6407-5296

Mirella Partyka (D) https://orcid.org/0000-0002-9936-6410

Paulina Romanowska (D) https://orcid.org/0000-0002-7429-9338

Klara Saczuk (D) https://orcid.org/0000-0002-4097-5430

Monika Magdalena Lukomska-Szymanska (D)

https://orcid.org/0000-0002-6110-4298

\section{References}

1. Bhanushali P, Katge F, Deshpande S, Chimata VK, Shetty S, Pradhan D. COVID-19: Changing trends and its impact on future of dentistry. Int J Dent. 2020;2020:8817424. doi:10.1155/2020/8817424

2. Spagnuolo G, De Vito D, Rengo S, Tatullo M. COVID-19 Outbreak: An overview on dentistry. Int J Environ Res Public Health. 2020;17(6):2094. doi:10.3390/ijerph17062094

3. Sokół-Szawłowska M. Wpływ kwarantanny na zdrowie psychiczne podczas pandemii COVID-19. Psychiatria. 2021;18(1):57-62. doi:10.5603/PSYCH.a2020.0046

4. Chowaniak K. Biznes w czasie epidemii : wpływ koronawirusa na polskie przedsiębiorstwa. Personel i Zarządzanie. 2020;5:10-15.

5. Alonzi S, La Torre A, Silverstein MW. The psychological impact of preexisting mental and physical health conditions during the COVID-19 pandemic. Psychol Trauma. 2020;12(S1):S236-S238. doi:10.1037/tra0000840

6. Khan KS, Mamun MA, Griffiths MD, Ullah I. The mental health impact of the COVID-19 pandemic across different cohorts. Int J Ment Health Addict. 2020:1-7. doi:10.1007/s11469-020-00367-0

7. Hawkins D. Differential occupational risk for COVID-19 and other infection exposure according to race and ethnicity. Am J Ind Med. 2020;63(9):817-820. doi:10.1002/ajim.23145

8. Checchi V, Bellini P, Bencivenni D, Consolo U. COVID-19 dentistryrelated aspects: A literature overview. Int Dent J. 2021;71(1):21-26. doi:10.1111/idj.12601

9. Podgórska M, Jakimiak B, Röhm-Rodowald E, Chojecka A. Assessment of disinfection and sterilization processes in dental practice as important factors in prevention of infections [in Polish]. Przegl Epidemiol. 2009;63(4):545-550.

10. Ahmed MA, Jouhar R, Ahmed N, et al. Fear and practice modifications among dentists to combat novel coronavirus disease (COVID-19) outbreak. Int J Environ Res Public Health. 2020;17(8):2821. doi:10.3390/ijerph17082821

11. Kawska W, Fils J, Jankowiak W, Anikiej P. Jak zmieniło się nasze życie w trakcie pandemii COVID-19? - badanie funkcjonowania psychospołecznego w czasie izolacji.Poszerzamyhoryzonty.2020;19(1):300-311. http://konferencjenaukowe.com.pl/wp-content/uploads/2020/07/ POSZERZAMY-HORYZONTY-TOM-XIX-cZ.-I.pdf. Accessed November 9, 2020.

12. Watt RG. COVID-19 is an opportunity for reform in dentistry. Lancet. 2020;396(10249):462. doi:10.1016/S0140-6736(20)31529-4

13. Cai $H, T u B, M a ~ J$, et al. Psychological impact and coping strategies of frontline medical staff in Hunan between January and March 2020 during the outbreak of coronavirus disease 2019 (COVID) in Hubei, China. Med Sci Monit. 2020;26:e924171. doi:10.12659/MSM.924171

14. Shacham M, Hamama-Raz Y, Kolerman R, Mijiritsky O, Ben-Ezra M, Mijiritsky E. COVID-19 factors and psychological factors associated with elevated psychological distress among dentists and dental hygienists in Israel. Int J Environ Res Public Health. 2020;17(8):2900. doi:10.3390/ijerph17082900

15. Spoorthy MS, Pratapa SK, Mahant S. Mental health problems faced by healthcare workers due to the COVID-19 pandemic - a review. Asian J Psychiatr. 2020;51:102119. doi:10.1016/j.ajp.2020.102119

16. Wu KK, Chan SK, Ma TM. Posttraumatic stress after SARS. Emerg Infect Dis. 2005;11(8):1297-1300. doi:10.3201/eid1108.041083

17. Lai J, Ma S, Wang $Y$, et al. Factors associated with mental health outcomes among health care workers exposed to coronavirus disease 2019. JAMA Netw Open. 2020;3(3):e203976. doi:10.1001/jamanetworkopen.2020.3976 
18. Vergara-Buenaventura A, Chavez-Tuñon M, Castro-Ruiz C. The mental health consequences of coronavirus disease 2019 pandemic in dentistry. Disaster Med Public Health Prep. 2020;14(6):e31-e34. doi:10.1017/dmp.2020.190

19. Mishra S, Singh S, Tiwari V, Vanza B, Khare N, Bharadwaj P. Assessment of level of perceived stress and sources of stress among dental professionals before and during the COVID -19 outbreak. J Int Soc Prev Community Dent. 2020;10(6):794-802. doi:10.4103/jispcd. JISPCD_340_20

20. Consolo U, Bellini P, Bencivenni D, lani C, Checchi V. Epidemiological aspects and psychological reactions to COVID-19 of dental practitioners in the Northern Italy districts of Modena and Reggio Emilia. Int J Environ Res Public Health. 2020;17(10):3459. doi:10.3390/ijerph17103459

21. Bhumireddy J, Mallineni SK, Nuvvula S. Challenges and possible solutions in dental practice during and post COVID-19. Environ Sci Pollut Res Int. 2021;28(2):1275-1277. doi:10.1007/s11356-020-10983-x

22. Coulthard P. Dentistry and coronavirus (COVID-19) - moral decisionmaking. Br Dent J. 2020;228(7):503-505. doi:10.1038/s41415-020-1482-1

23. Meng L, Hua F, Bian Z. Coronavirus disease 2019 (COVID-19): Emerging and future challenges for dental and oral medicine. J Dent Res. 2020;99(5):481-487. doi:10.1177/0022034520914246

24. Diegritz C, Manhart J, Bücher K, et al. A detailed report on the measures taken in the Department of Conservative Dentistry and Periodontology in Munich at the beginning of the COVID-19 outbreak. Clin Oral Investig. 2020;24(8):2931-2941. doi:10.1007/s00784-020-03440-z

25. Marui VC, Silveira Souto ML, Rovai ES, Romito GA, Chambrone L, Pannuti CM. Efficacy of preprocedural mouthrinses in the reduction of microorganisms in aerosol: A systematic review. J Am Dent Assoc. 2019;150(12):1015-1026.e1. doi:10.1016/j.adaj.2019.06.024

26. Westgarth D. How does dentistry move from survival to revival? BDJ In Pract. 2020;33:12-16. doi:10.1038/s41404-020-0483-8

27. Schwendicke F, Krois J, Gomez J. Impact of SARS-CoV2 (Covid-19) on dental practices: Economic analysis. J Dent. 2020;99:103387. doi:10.1016/j.jdent.2020.103387

28. Cavalcanti YW, Oliveira da Silva R, de Freitas Ferreira L, et al. Economic impact of new biosafety recommendations for dental clinical practice during COVID-19 pandemic. Pesqui Bras Odontopediatria Clín Integr. 2020;20(Suppl 1):e0133. doi:10.1590/pboci.2020.143

29. Ghai S. Teledentistry during COVID-19 pandemic. Diabetes Metab Syndr. 2020;14(5):933-935. doi:10.1016/j.dsx.2020.06.029

30. Jampani ND, Nutalapati R, Dontula BSK, Boyapati R. Applications of teledentistry: A literature review and update. J Int Soc Prev Community Dent. 2011;1(2):37-44. doi:10.4103/2231-0762.97695

31. Gopal Reddy KV. Using teledentistry for providing the specialist access to rural Indians. Indian J Dent Res. 2011;22(2):189. doi:10.4103/0970-9290.84275

32. Bhambal A, Saxena S, Balsaraf SV. Teledentistry: Potentials unexplored! J Int Oral Heal. 2010;2(3):1-6. https://www.ispcd.org/ userfiles/rishabh/jioh-02-03-01.pdf. Accessed November 9, 2020.

33. Chang SW, Plotkin DR, Mulligan R, Polido JC, Mah JK, Meara JG. Teledentistry in rural California: A USC initiative. J Calif Dent Assoc. 2003;31(8):601-608. PMID:13677402.

34. Golder DT, Brennan KA. Practicing dentistry in the age of telemedicine. J Am Dent Assoc. 2000;131(6):734-744. doi:10.14219/jada. archive.2000.0272

35. Weerasinghe JU. Clinical trials on computer based telemedicine: A systematic review. Sri Lanka J Biomed Inform. 2010;1(1):12-20. doi:10.4038/sljbmi.v1i1.1481

36. Simon L. How will dentistry respond to the coronavirus disease 2019 (COVID-19) pandemic? JAMA Health Forum. 2020;1(5):e200625. doi:10.1001/jamahealthforum.2020.0625

37. Duka M, Mihailović B, Miladinović $M$, Janković A, Vujicić B. Evaluation of telemedicine systems for impacted third molars diagnosis [in Serbian]. Vojnosanit Pregl. 2009;66(12):985-991. doi:10.2298/vsp0912985d

38. Berndt J, Leone P, King G. Using teledentistry to provide interceptive orthodontic services to disadvantaged children. Am J Orthod Dentofac Orthop. 2008;134(5):700-706. doi:10.1016/j.ajodo.2007.12.023

39. Kopycka-Kedzierawski DT, Billings RJ. Prevalence of dental caries and dental care utilisation in preschool urban children enrolled in a comparative-effectiveness study. Eur Arch Paediatr Dent. 2011;12(3):133-138. doi:10.1007/BF03262794
40. Rose S. Medical student education in the time of COVID-19. JAMA. 2020;323(21):2131-2132. doi:10.1001/jama.2020.5227

41. Fagbule OF. 2019 novel coronavirus. Ann lb Postgrad Med. 2019;17(2):108-110. PMID:32669985. PMCID:PMC7358814.

42. Ruiz JG, Mintzer MJ, Leipzig RM. The impact of e-learning in medical education. AcadMed. 2006;81(3):207-212. doi:10.1097/00001888200603000-00002

43. Huynh R. The role of e-learning in medical education. Acad Med. 2017;92(4):430. doi:10.1097/ACM.0000000000001596

44. Theoret C, Ming X. Our education, our concerns: The impact on medical student education of COVID-19. Med Educ. 2020;54(7):591-592. doi:10.1111/medu.14181

45. Janakiram C, Nayar S, Varma B, et al. Dental care implications in coronavirus disease-19 scenario: Perspectives. J Contemp Dent Pract. 2020;21(8):935-945. doi:10.5005/jp-journals-10024-2896

46. Deery C. The COVID-19 pandemic: Implications for dental education. Evid Based Dent. 2020;21(2):46-47. doi:10.1038/s41432-020-0089-3

47. Cleland J, McKimm J, Fuller R, Taylor D, Janczukowicz J, Gibbs T. Adapting to the impact of COVID-19: Sharing stories, sharing practice. Med Teach. 2020;42(7):772-775. doi:10.1080/0142159X.2020.1757635

48. Bennardo F, Buffone C, Fortunato L, Giudice A. COVID-19 is a challenge for dental education - a commentary. Eur J Dent Educ. 2020;24(4):822-824. doi:10.1111/eje.12555

49. Gao X, Wong LM, Chow DYS, Law XJ, Ching LYL. Learning clinical procedures through Internet visual resources: A qualitative study amongst undergraduate students. Eur J Dent Educ. 2015;19(1):38-43. doi:10.1111/eje.12099

50. MacLeod A, Kits O, Mann K, Tummons J, Wilson KW. The invisible work of distributed medical education: Exploring the contributions of audiovisual professionals, administrative professionals and faculty teachers. Adv Health Sci Educ Theory Pract. 2017;22(3):623-638. doi:10.1007/s10459-016-9695-4 